\title{
Survival Outcomes in Merkel Cell Carcinoma of the Head \& Neck
}

\section{Introduction}

Merkel cell (MCC) is a highly aggressive cutaneous malignancy, commonly presenting in the head \& carcinoma neck. In this retrospective study we compare actuarial 5-year outcomes based on location of primary site.

\section{Results}

A total of 44 cases of MCC were identified from interrogation of the Northern Ireland regional cancer registry. The primary site was in the head \& neck in 27/44 patients (61\%) and in the limbs in 17/44 (39\%). Comparative clinicopathological features of the two groups are shown in table 1.

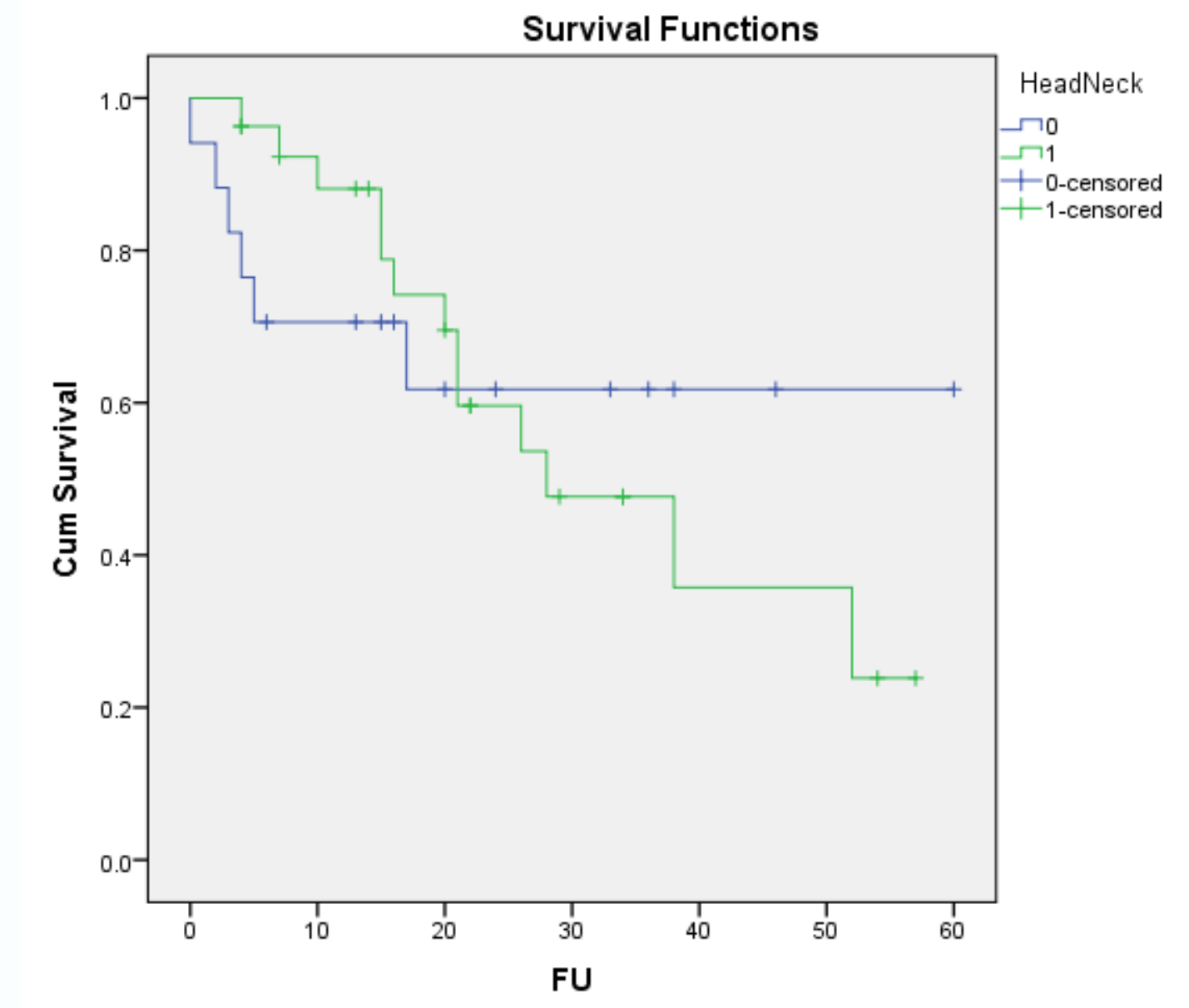

Fig 1. Overall survival for MCC in head \& neck (green line) vs. non-head \& neck (blue line) primary sites.

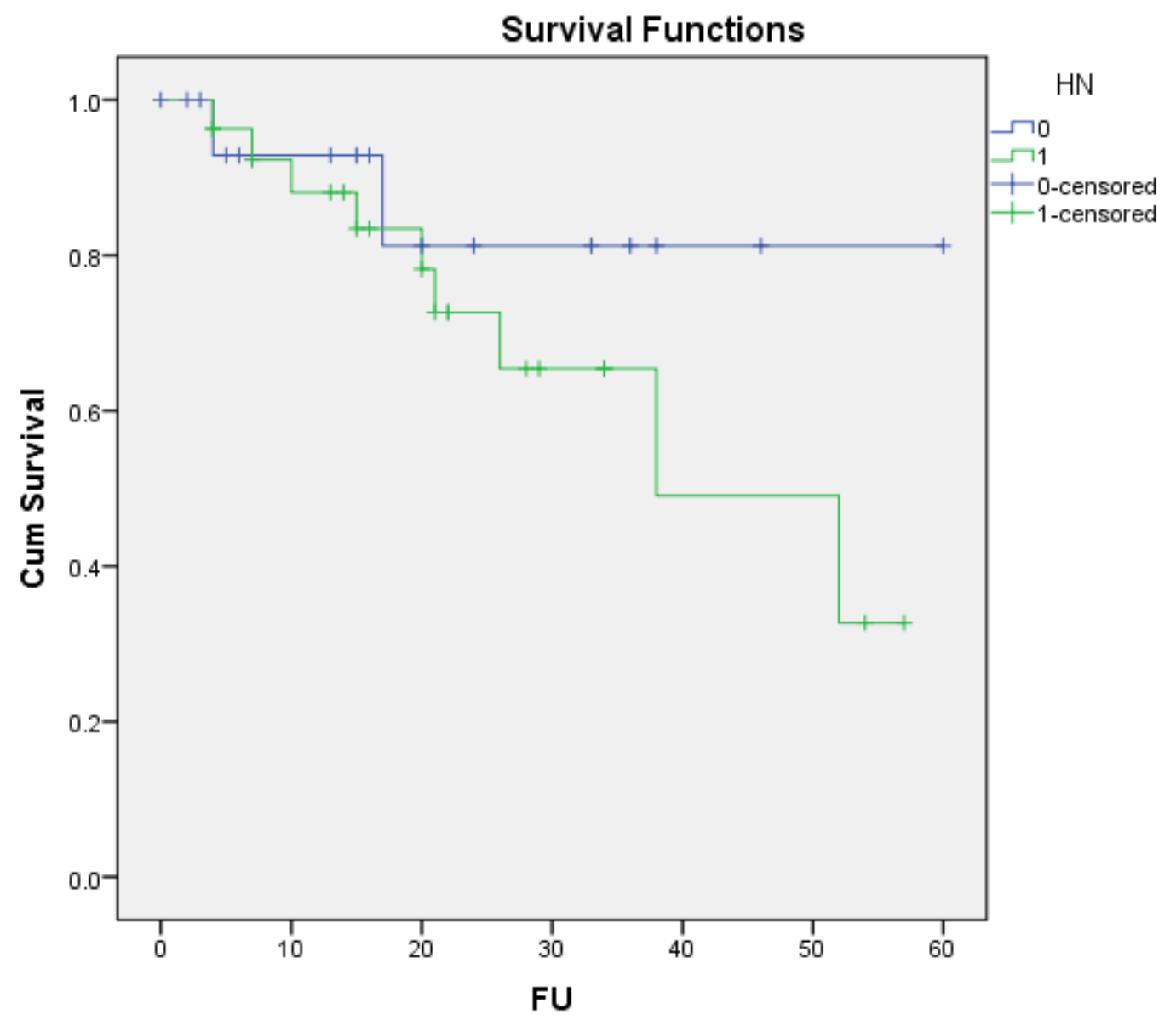

Fig 2. Disease-specific survival for $M C C$ in head \& neck (green line) vs. non-head \& neck (blue line) primary sites.

Median overall survival for the entire cohort of 44 patients was 39 months (mean 35, 95\% confidence interval [Cl] 10.759.1 months) with an actuarial 5 year survival rate of $33 \%$. Overall \& disease-specific survival based on primary tumour site are shown in figures $1 \& 2$. Five year overall survival was $24 \%$ in the H\&N group and $62 \%$ in the non-H\&N group ( $p=$ 0.83 ). Disease specific 5 year survival was $33 \%$ in the $H \& N$ group and $81 \%$ in the non-H\&N group $(p=0.29)$.

\section{Discussion}

\begin{tabular}{|c|c|c|c|}
\hline $\begin{array}{c}\text { Characteristic } \\
\mathrm{N}=/ \%\end{array}$ & $H \& N(N=27)$ & $\begin{array}{c}\text { Non-H\&N } \\
(\mathrm{N}=17)\end{array}$ & $P$ value \\
\hline Age (median) & 81 & 83 & 0.88 \\
\hline $\begin{array}{l}\text { Sex } \\
\qquad \text { Male } \\
\text { Female }\end{array}$ & $\begin{array}{l}18(67) \\
9(33)\end{array}$ & $\begin{array}{l}8(47) \\
99(53)\end{array}$ & 0.66 \\
\hline $\begin{array}{c}\text { T Stage } \\
\text { T0 } \\
\text { T1 } \\
\text { T2 } \\
\text { T3 } \\
\text { T4 }\end{array}$ & $\begin{array}{c}2(7) \\
21(27) \\
2(7) \\
1(4) \\
1(4)\end{array}$ & $\begin{array}{c}1(6) \\
4(24) \\
7(41) \\
4(24) \\
1(6)\end{array}$ & $<0.05$ \\
\hline $\begin{array}{l}\text { N Stage } \\
\text { cN0 } \\
\text { pNO } \\
\text { N1a } \\
\text { N1b } \\
\text { N2 }\end{array}$ & $\begin{array}{c}19(70) \\
0 \\
0 \\
7(28) \\
1(4)\end{array}$ & $\begin{array}{c}11(65) \\
0 \\
0 \\
6(35) \\
0\end{array}$ & 0.91 \\
\hline $\begin{array}{l}\text { M Stage } \\
\text { M0 } \\
\text { M1 }\end{array}$ & $\begin{array}{l}25(93) \\
2(7)\end{array}$ & $\begin{array}{c}16(94) \\
1(6)\end{array}$ & 0.68 \\
\hline $\begin{array}{l}\text { AJCC Stage } \\
\text { I } \\
\text { II } \\
\text { III } \\
\text { IV }\end{array}$ & $\begin{array}{l}15(56) \\
2(7) \\
7(26) \\
3(11)\end{array}$ & $\begin{array}{c}3(18) \\
8(47) \\
5(29) \\
1(6)\end{array}$ & 0.01 \\
\hline $\begin{array}{l}\text { Treatment } \\
\text { Surgery } \\
\text { Surgery \& PORT } \\
\text { Palliation }\end{array}$ & $\begin{array}{c}33(75) \\
8(18) \\
3(7)\end{array}$ & $\begin{array}{c}16(76) \\
3(18) \\
1(6)\end{array}$ & 0.96 \\
\hline $\begin{array}{l}\text { Margin } \\
\text { Close }(\leq 5 \mathrm{mmm}) \\
\text { Clear }(>5 \mathrm{~mm})\end{array}$ & $\begin{array}{l}16(70) \\
7(30)\end{array}$ & $\begin{array}{l}11(69) \\
5(31)\end{array}$ & 1.00 \\
\hline $\begin{array}{l}\text { Lymphovascular Invasion } \\
\text { Present } \\
\text { Absent }\end{array}$ & $\begin{array}{c}9(41) \\
13(59)\end{array}$ & $\begin{array}{l}7(44) \\
9(56)\end{array}$ & $\begin{array}{c}1 \\
0.86\end{array}$ \\
\hline
\end{tabular}

Merkel cell carcinoma is a rare but aggressive neuroendocrine cutaneous malignancy. It is more common in those aged over 65 and in Caucasians ${ }^{1}$. In this study, patients with a primary lesion in the head and neck had poorer overall ( $24 \%$ vs $62 \%$ ) and disease specific ( $33 \%$ vs $81 \%$ ) 5 year survival when compared to those with infra-clavicular primary sites. This was despite the fact that the $\mathrm{H} \& \mathrm{~N}$ group had a statistically significantly higher proportion of early T-stage $(p<0.05)$ and overall AJCC stage $(p=0.01)$ disease. While the differences observed in our study did not reach statistical significance this is likely the results of its small size $(\mathrm{N}=44)$. Larger multi-centre studies of this rare cancer are likely required to clarify this relationship further although this finding has also been observed in other series ${ }^{2}$, although the effect size was somewhat smaller. We hypothesise that the rich lymphatic and vascular drainage of the head \& neck may predispose patients to distant recurrence and therefore higher mortality. Patients with primary MCC of the H\&N may therefore require wider surgical margins or radiotherapy treatment volumes than those with primary tumours in the trunk or limbs.

References

1. Bichakjian et al. Merkel cell carcinoma: critical review with guidelines for multidisciplinary management. Cancer 2007;110(1):1-12 